\title{
ORDEN POLÍTICO Y PRINCIPIOS DE REFORMA TRIBUTARIA: UN ANÁLISIS EN PERSPECTIVA HISTÓRICA
}

\author{
Zulema Calderón Corredor
}

doi: 10.18543/ed-63(2)-2015pp47-80

\begin{abstract}
SuMARIO: 1. InTRODUCCIÓN. 2. ANÁLISIS HISTÓRICO. 1. Cosmovisión realista. 1.1. El conocimiento por las causas. 1.2. Naturaleza humana: hombre como ser social y politico. 1.3. Orden politico y bien común. 1.4. Justicia como virtud, derecho como reparto. 1.5. Impuesto justo por sus causas. 2. Cosmovisión moderna. 2.1. Del realismo al paradigma de la certeza. 2.2. Del hombre social al individuo egoísta. 2.3. Del orden al contrato. 2.4. De la virtud a la idea, del reparto al poder. 2.5. El impuesto equitativo. 3. Cosmovisión cientificista. 3.1. Del racionalismo al método científico. 3.2. Del individuo a la sociedad. 3.3. Del estado protector al estado benefactor. 3.4. Justicia como derecho positivo. 3.5. Principio de justicia en los tributos. 4. Cosmovisión postmoderna. 4.1. Del positivismo al relativismo. 4.2. Nihilismo y bienestar. 4.3. Estado de bienestar: consolidación y crisis. 4.4. Formalismo y constructivismo jurídicos. 4.5. Del Estado social al estado fiscal. 3. Algunas CONCLUSIONES. 4. Bibliografía.
\end{abstract}

\section{INTRODUCCIÓN}

La primera década del siglo XXI se encuentra marcada por importantes movimientos de reforma fiscal en muchos Estados europeos. Los efectos derivados de la reciente crisis económica y la situación de las financias públicas han sido las variables que más han influido a la hora de situar al fenómeno tributario como protagonista de la acción política. 
Del análisis de los sistemas tributarios actuales y de las propuestas de reforma que en ellos se contienen, sobresale el esfuerzo por hacer compatibles objetivos tributarios tradicionalmente enfrentados, como los redistributivos y recaudatorios con las restricciones que impone el contexto económico, en el Informe Mirrlees de Reino Unido ${ }^{1}$, o como los recaudatorios y la eficiencia económica en el caso del Informe español de la Comisión de Expertos para la Reforma Fiscal ${ }^{2}$, por ejemplo.

No obstante, estos trabajos de reflexión y propuesta de reforma, no se encuentran acompañados de un activo debate político, social y doctrinal relativo a la posible reconsideración del modelo actual, desde el punto de vista de las funciones del Estado y con ello desde la finalidad del gasto público y del sistema tributario. Es decir, las propuestas de reforma fiscal deberían estar inspiradas en un proceso continuo de búsqueda del bien sustantivo de las sociedades a las que sirven, especialmente en una coyuntura de crisis como la presente que, además de tener causas económicas, puede ser síntoma de un agotamiento de los modelos sociales y políticos vigentes.

Pues bien, como medio para reflexionar sobre ese bien sustantivo, se propone un breve análisis sobre la relación que existe entre el orden político y los principios de reforma tributaria que se han sucedido a lo largo de la historia en Europa Occidental. Este análisis comprenderá el de las concepciones que acerca del conocimiento, el hombre y de la sociedad les han servido de sustrato, en la medida en que estas concepciones se han proyectado en las formas históricas de organización política y en el papel adoptado por los sistemas tributarios. Con ello se busca comprender mejor cuál es la influencia del modelo antropológico y político de referencia en los principios inspiradores de las reformas fiscales, los fines o la ausencia de ellos, que han ido posicionando a los sistemas fiscales modernos en su realidad y vicisitudes. La profundización en sus elementos constitutivos y en la forma de entender el fenómeno tributario puede iluminar la tarea de proponer una dirección de propósito para posibles reformas tributarias.

Con este objetivo, y sin detenerse en realidades espacial o temporalmente concretas, se propone un análisis histórico de los elementos anteriores en el marco de las cosmovisiones ${ }^{3}$ que históricamente se han sucedido. Se analizarán por orden cronológico las cosmovisiones realista, desde Aristóteles al

${ }^{1}$ Mirrlees, J. et. Alt.: Diseño de un sistema tributario óptimo. Informe Mirrlees, Introducción y traducción de Julio Viñuela Díaz, Centro de estudios Ramón Areces (1. ${ }^{\text {a }}$ edición inglesa de 2011), 2013.

${ }^{2}$ Informe publicado en febrero de 2013 como resultado de los trabajos de la Comisión creada por medio de los Acuerdos del Consejo de Ministros de 5 de julio y de 8 de noviembre de 2013.

${ }^{3}$ Cosmovisión: Manera de ver e interpretar el mundo (RAE). 
inicio del nominalismo (siglo XIV), la moderna, desde el nominalismo al positivismo científico (siglo XIX), la cientificista (hasta mediados del siglo XX), y la post-moderna, hasta la época actual ${ }^{4}$.

\section{ANÁLISIS HISTÓRICO}

\section{Cosmovisión realista}

\subsection{El conocimiento por las causas}

La remisión histórica al realismo aristotélico como primera etapa de este análisis, responde a la búsqueda de las fuentes y presupuestos que acompañaron a la formulación primigenia de elementos clave de este estudio: el concepto de justicia y de Derecho y la cuestión del orden político ${ }^{5}$. El adjetivo realista sobresale del resto, no obstante, pues tanto la filosofía jurídica como la teoría del estado que se elaboraron sobre las aportaciones de Aristóteles, lo hicieron desde una particular concepción sobre las posibilidades del conocimiento humano. «Todos los hombres desean por naturaleza saber» ${ }^{6} \mathrm{y}$ «sabemos una cosa cuando creemos conocer su causa primera» ${ }^{7}$. En ese proceso juegan un papel importante los sentidos, la memoria, el razonamiento y la experiencia ${ }^{8}$ a través de los cuáles se llega al conocimiento de las cosas concretas «que están ahí»?.

Esta forma de entender la realidad se denominó realista frente al empirismo y a la visión platónica precedentes. El conocimiento de una cosa se materializa así en el de sus causas ${ }^{10}$ y de sus fines o hacia dónde tienden. Si se

${ }^{4}$ Un desarrollo más detallado sobre la cuestión en: CALDERON CoRredor, Z.: Los principios impositivos de equidad y eficiencia en el sistema fiscal español: una perspectiva antropológica, Tesis doctoral inédita, 2014.

${ }_{5}$ En ambas cuestiones puede decirse que la influencia de Aristóteles ha sido decisiva en la Historia de Occidente, y especialmente en los quince siglos siguientes. En el Libro V de su Ética a Nicómaco Aristóteles delimita las fronteras del arte jurídico, la especialidad del mismo frente a otros artes y otras ciencias y con ello delimita también el objeto del Derecho. Existe abundante bibliografía que se ocupa de esta cuestión. Por todos, puede citarse la siguiente: VAllet DE Goytisolo, J. B.: «¿Qué es el realismo? Distintas perspectivas con las cuales se enfoca su significado», Anales de la Real Academia de Ciencias Morales y Políticas, n. ${ }^{\circ}$ 78, 2001, pp. 583-605; En su Política se contienen algunas de las aportaciones doctrinales más importantes de la historia de la Ciencia Política.

${ }^{6}$ Aristóteles, Metafísica, Edición trilingüe por Valentín García Yebra, 2. ${ }^{\mathrm{a}}$ ed. [19701], Madrid, Gredos, 1990, p. 2.

7 Ibidem, p. 19.

${ }^{8}$ Ibidem, p. 4.

9 CORTS GRAU, J.: Historia de la filosofía del derecho. 2. ${ }^{\mathrm{a}}$ ed., Editora Nacional, Madrid, 1968, pp. 134 y ss.

${ }^{10}$ «... una de las cuales decimos que es la substancia y la esencia (pues el porqué se reduce al concepto último, y el porqué primero es causa y principio); otra es la materia o 
acepta que la realidad puede conocerse, aunque sea imperfectamente, y es la que es, se acepta también implícitamente que puede existir un orden externo inteligible que pueda ser relevante descubrir.

\subsection{Naturaleza humana: hombre como ser social y político}

Para entender la teoría política que propone y su concepto de justicia, hay que detenerse primero en conocer su idea de hombre. Como hiciera para conocer otras realidades, en la humana también identifica una esencia o naturaleza ${ }^{11}$, y un fin, la felicidad, aunque reconoce que «las naturalezas vulgares y groseras creen que la felicidad es el placer... $»^{12}$. Sin embargo, enseguida explica por qué entiende que la felicidad del hombre se encuentra en la virtud $^{13}$, cuestión a la que dedica la práctica totalidad de su Ética nicomaquea. En su recapitulación final sobre la teoría de la felicidad retoma de nuevo la cuestión de la virtud y la relaciona con su idea del hombre, explicando cómo los actos dignos de ser amados y preferidos son los que resultan conformes a la manera del ser del hombre ${ }^{14}$, que es una y determinada. De esta forma, naturaleza humana y felicidad se encuentran indisolublemente unidas al concepto de virtud, y a través de ella a la relación que mantiene el hombre con el resto de sus semejantes.

Conforme a la teoría aristotélica en torno a las virtudes humanas ${ }^{15}$ el bien del hombre no puede separarse del bien de los que forman la comunidad. Es por ello que Aristóteles afirma que se trata de un ser social, que tiende de

el sujeto; la tercera, aquella de donde procede el principio del movimiento, y la cuarta, la que se opone a ésta, es decir, la causa final o el bien (pues éste es el fin de cualquier generación y movimiento)». ARISTÓTELES, Metafísica, Edición trilingüe por Valentín García Yebra, 2. ${ }^{\mathrm{a}}$ ed. [1970'1], Madrid, Gredos, 1990, p. 19.

${ }^{11}$ «Lo que cada ser es, después de cumplirse el desarrollo, eso decimos que es su naturaleza, así de un hombre, de un caballo o de una casa. Además, la causa final y la perfección es lo mejor.» ARISTÓTELES, La política, Edición preparada por Carlos García

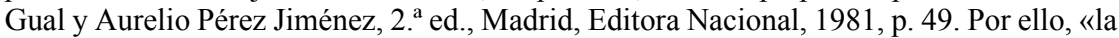
naturaleza significa algo crucial en la comprensión del mundo...la naturaleza significa el enraizamiento del devenir en el ser, esto es, que en el obrar de cada ente natural se manifiesta el mismo ser del que obra y así, no solo lo finito y contingente sino incluso lo cambiante, manifiesta en este su movimiento, un modo de ser». Petit Sullá, José M.a : Obras Completas. Tomo II, Vol. II, Tradere, 2011, p. 544.

12 Aristóteles: Ética nicomaquea, Traducción y notas de Patricio de Azcárate, Buenos Aires, Losada, 2004 (2004), p. 15.

13 Ibídem, p. 36.

14 Ibídem, p. 384.

15 Macintyre, A.: Tras la virtud. Traducción castellana de Amelia Valcarce, [2001'], 4. ${ }^{a}$ ed., Crítica, Barcelona, 2009 (2009), pp. 281-282. Su teoría sobre la virtud como forma en la que el hombre alcanza su fin (la felicidad), junto con la amistad y la justicia, fue 
forma natural a vivir en comunidad ${ }^{16}$. No obstante, «el hombre no sólo es social, como lo son otros animales, sino que es también político, y sólo él es tal. La polis es la condición de la vida humana buena, de una vida humana dotada de aquella plenitud que a la esencia del hombre como animal racional corresponde $\gg{ }^{17}$. Esta concepción sobre la forma de ser del hombre y su vida es la que traslada a su teoría política y la que recogerá la tradición escolásti$\mathrm{ca}^{18}$ hasta proyectarla en otros ámbitos, como el jurídico y el tributario.

\subsection{Orden político y bien común}

Aristóteles dedica el Libro VI de La Política a determinar cuál es el régimen más perfecto, pero para ello cree necesario investigar primero qué tipo de vida es el más deseable «pues si se ignora esto se ignorará también el régimen más deseable» ${ }^{19}$. Concluye el capítulo primero de este libro afirmando que «la forma mejor de vida para cada individuo en particular y para las ciudades en general es la que cuenta con una virtud dotada de recursos suficientes como para intervenir en las acciones virtuosas... $\rangle^{20}$.

Santo Tomás se refiere al orden político como a una realidad superior a la suma de sus miembros, una unidad de actuación con arreglo a un fin, una unidad de orden, en la que el bien individual se somete al bien común sin ser absorbido por éste. El bien común, «este que hace posible precisamente el armonioso despliegue de la personalidad ${ }^{21}$, es el fin de la sociedad política. Es así como la cuestión de la naturaleza humana, la tradición de las virtudes y la cuestión del fin, quedan vinculadas a la teoría política y, por extensión, a la teoría jurídica y tributaria o teoría del impuesto justo.

desarollada por Aristóteles en sus tratados sobre teoría moral: Ética eudemia, La gran moralia y la Ética nicomaquea.

16 ARISTÓTeles: La política, Edición preparada por Carlos García Gual y Aurelio Pérez Jiménez, 2. ${ }^{a}$ ed., Madrid, Editora Nacional, 1981, pp. 49-50.

17 Truyol y Serra, A.: Historia de la Filosofía del Derecho y del Estado.1.De los orígenes a la baja edad media. 14. ${ }^{\mathrm{a}}$ ed., (Revista de Occidente, 1954'1), Alianza, Madrid, 2004, p. 161.

18 SAn Agustín la recoge en su filosofía social y política al igual que SANTo ToMÁs. Truyol y SERra, A.: Historia de la Filosofía del Derecho y del Estado.1.De los orígenes a la baja edad media. 14. ' ed., (Revista de Occidente, 1954'), Alianza, Madrid, 2004, pp. 266-267 y 372-373 respectivamente.

19 Aristóteles (1981): La política, Edición preparada por Carlos García Gual y Aurelio Pérez Jiménez, 2. ${ }^{\text {a }}$ ed., Editoria Nacional, Madrid, 1981, p. 275.

${ }^{20}$ Ibidem, p. 277.

${ }^{21}$ Truyol y Serra, A.: Historia de la Filosofia del Derecho y del Estado.1.De los orígenes a la baja edad media. 14. ${ }^{\text {a }}$ ed., (Revista de Occidente, 1954'), Alianza, Madrid, 2004, p. 373. 


\subsection{Justicia como virtud, derecho como reparto}

El objeto del Derecho, la justicia y su fin, el reparto, se sostienen también sobre la realidad humana en la que espontáneamente surgen. Su origen y existencia responden a las condiciones de tiempo y espacio en que el hombre vive, a su naturaleza social, al reparto de funciones que se produce en la comunidad, y a cómo de todo ello se deriva la necesidad de que exista un reparto de las cosas, de que las mismas estén atribuidas a personas concretas ${ }^{22}$.

La noción de justicia, siendo la más importante de toda la filosofía jurídica y fundamental en la política, fue delimitada y vinculada con el arte jurídico dentro del estudio de las virtudes. Es allí donde ARISTÓTELES consiguió identificar en el significado general atribuido a la justicia como virtud ${ }^{23}$, un sentido específico, propio, la quintaesencia del $\mathrm{mismo}^{24}$, delimitando así las fronteras del arte jurídico, su especialidad frente a otras artes y ciencias y con ello identificar el objeto del Derecho. Así, la justicia entendida en sentido estricto, la justicia particular, es la virtud según la cuál alguien «no toma más que su parte de los bienes exteriores disputados por un grupo social, ni menos del pasivo, de las cargas... $\rangle^{25}$ siendo la finalidad de este tipo de justicia el que cada uno tenga lo suyo ${ }^{26}$, el suum, su derecho, tarea de los jueces y del arte jurídico y conforme al criterio de medida contenido en el Derecho, un reparto sobre bienes exteriores.

La justicia, identificable con una relación de igualdad, puede adoptar distintas formas de medida según la posición en que se encuentren las partes, pues son también distintas las formas de relación humana que pueden encontrarse en la vida en común. Por ello, la justicia particular puede hacerse efectiva desde dos formas: conmutativa o reparadora ${ }^{27}$, relativa a las relaciones de los individuos entre sí y distributiva o asignadora, realizable en las relaciones entre la comunidad o grupo y cada uno de sus miembros indivi-

${ }^{22}$ Hervada Xiberta, J.: ¿Qué es el derecho? La moderna respuesta del realismo jurídico. Eunsa, 2. ${ }^{\mathrm{a}}$ ed, Pamplona, 2008, pp. 33 y ss.

${ }^{23}$ Del análisis de Aristóteles sobre la justicia se desprenden dos sentidos atribuibles al término. De un lado estaría la justicia desde un sentido amplio, la virtud entera o justicia general, entendida como la suma de todas las virtudes o la conformidad con la ley moral, aunque sin confundirse con la moralidad plena. ARISTÓTELES: Ética nicomaquea, Traducción y notas de Patricio de Azcárate, Buenos Aires, Losada, 2004, pp. 163-167. La justicia así entendida desborda ampliamente los límites del Derecho.

${ }^{24}$ Villey, M.: Filosofía del Derecho. Traducción de Evaristo Palomar Maldonado, Scire Universitaria, Barcelona, 2003, pp. 50-51.

${ }_{25}$ Ibídem, pp. 50-51.

${ }^{26}$ Vitoria, F. DE, La Justicia. Estudio preliminar y traducción de Luis Fraile Delgado. Tecnos, Madrid, 2001, p. 12.

27 ArISTÓTELES: Ética nicomaquea, Traducción y notas de Patricio de Azcárate, Losada, Buenos Aires, 2004, p. 175. 
dualmente considerados. Esta última tendrá especial relevancia en el ámbito tributario.

\subsection{Impuesto justo por sus causas}

El pago de los tributos, para un hombre que por naturaleza vive y se desarrolla en comunidad, resulta natural y espontáneo y queda vinculado a los fines que son propios de esa convivencia. Las aportaciones más relevantes del pensamiento medieval y de la doctrina escolástica (siglos XI-XVII) ${ }^{28}$ sobre qué hace justo a un impuesto, se fundamentan en la identificación de sus causas. Además del fin del tributo o su ordenación al bien común (causa final), se señalan como necesarios su aprobación por la autoridad competente (causa eficiente), la existencia previa de capacidad económica (causa material) y su reparto proporcional (causa formal).

La medida del gravamen es la que aporta la justicia distributiva, puesto que se trata de un reparto que se circunscribe mayormente a relaciones que mantiene la comunidad con sus miembros ${ }^{29}$. «Así pues, lo justo es algo proporcional...Este tipo de relación entre las cosas y las personas es el tipo de la justicia distributiva y la proporción que se le aplica es la geométrica $»^{30}$. Para que dicha proporción pueda materializarse, es necesario determinar qué condición o circunstancia diferencia a unos ciudadanos de otros y es relevante a efectos impositivos. El criterio dependerá de la relación que guarde el destinatario del tributo con el fin del reparto, y siendo los tributos la forma de atender a las cargas públicas, fue la capacidad económica para afrontarlas la que se consideró como condición más relevante. Este criterio se constituyó para SANTO TOMÁS y la doctrina escolástica posterior en la piedra angular para la realización de la justicia distributiva en materia de impuestos ${ }^{31}$.

${ }^{28}$ SANTO TOMÁs desarrolla la doctrina del impuesto justo como un caso particular de los requisitos que deben cumplir las leyes humanas para obligar en conciencia, ocupando un lugar fundamental en esos requisitos tanto el fin del tributo como la forma del reparto de la carga. Aquino, S. T. DE,: Suma de Teología II, parte I-II (Prima secundae), Madrid, BAC. 1989, q. 96. a. 4. 750-751. Referencias a esta cuestión en las aportaciones de la Escuela de Salamanca pueden encontrarse, entre otros, en GorosQuiETA REYES, J.: «El sistema de ideas tributarias de los teólogos y moralistas principales de la escuela de Salamanca», Hacienda Pública Española, n. ${ }^{\circ}$ 17, 1972, pp. 131-150; y GóMEz CAMACHO, F.: Economía y filosofía moral: la formación del pensamiento económico europeo en la Escolástica española, Síntesis, Madrid. 1998, pp. 293-307.

29 ARISTÓTELEs: Ética nicomaquea, Traducción y notas de Patricio de Azcárate, Losada, Buenos Aires, 2004, p. 172.

${ }^{30}$ Ibidem, p. 173.

31 PÉrez De AyAla, J.L.: «El fundamento deontológico del impuesto, de la Ley fiscal y de la obligación tributaria», en AA. VV. I Jornada Metodológica «Jaime García Año- 
Cuando se enumeran los requisitos del impuesto justo, las llamadas «causas del impuesto», implícitamente estos autores están considerando todos los elementos necesarios para dar también respuesta al problema de la medida concreta en la contribución proporcional, es decir, al problema del quantum. No es de extrañar que no hicieran referencia a una proporción concreta, pues la misma debería estar en estrecha dependencia con la finalidad del impuesto, con las necesidades a satisfacer con el mismo y por ello, con su magnitud total habida cuenta del concepto de bien común de referencia y del papel atribuible al impuesto en su realización.

\section{Cosmovisión moderna}

\subsection{Del realismo al paradigma de la certeza}

Desde el siglo XIV comienzan a difundirse una serie de corrientes filosóficas que con el tiempo transformarán la concepción vigente ${ }^{32}$ de las posibilidades del conocimiento humano, y con ello la concepción vigente acerca del hombre y su vida en común. La relación mantenida hasta el momento entre el hombre y la realidad es cuestionada, al igual que la posibilidad de un conocimiento de carácter objetivo.

Con el nominalismo de GUILLERMO DE OCKHAM (1280-1349) se inicia la división entre la realidad y el pensamiento subjetivo ${ }^{33}$ pues este ya no es representación de la primera sino solo un signo de ella. Tampoco hay orden, ni órdenes propiamente dichos, hay cosas. Desaparece también la idea de orden natural de carácter teleológico ${ }^{34}$. Comienza a dibujarse asimismo el principio de inmanencia según el cuál el hombre no conoce más que sus pensamientos pero no puede afirmar que reflejen la verdad de la realidad. Esta cuestión constituye el germen del moderno escepticismo filosófico ${ }^{35}$.

veros» sobre la metodología académica y la enseñanza del Derecho Financiero y Tributario. Instituto de Estudios Fiscales. Documentos 11/2002, 2002, p. 288; GómEZ CAMACHO, F.: Economía y filosofía moral: la formación del pensamiento económico europeo en la Escolástica española, Síntesis, Madrid. 1998, p. 305; GorosQuiETA ReYES, J.: «El sistema de ideas tributarias de los teólogos y moralistas principales de la escuela de Salamanca», Hacienda Pública Española, n. ${ }^{\circ}$ 17, 1972, p. 146.

32 Truyol y Serra, A.: Historia de la Filosofía del Derecho y del Estado.1.De los orígenes a la baja edad media. 14. ${ }^{\mathrm{a}}$ ed., (Revista de Occidente, 1954 ${ }^{1}$ ), Alianza, Madrid, 2004, pp. 409 y ss.

33 Valverde, C. (1996): Génesis, estructura y crisis de la modernidad. BAC, Madrid, 1996, pp. 10 y ss.

${ }^{34}$ Spaemann, R.: «Sobre la ontología de derechas e izquierdas», Anuario filosófico, n. ${ }^{\circ} 17,1984$, p. 80.

${ }_{35}$ VAlverde, C.: Génesis, estructura y crisis de la modernidad, BAC, Madrid, 1996, p. 146. 
Con el desarrollo del método matemático difundido por GALILEO (15641642), la Matemática será considerada por muchos como la ciencia reina y muchas otras ciencias tenderán a aplicar su método aunque difieran en su objeto de conocimiento. Buena muestra de su influencia es el sistema de pensamiento diseñado por DESCARTES (1596-1650) a partir de un nuevo método $^{36}$ que provoque en el lector una certeza y seguridad similares a los que ofrecen las matemáticas.

Como una reacción frente al racionalismo extremo continental de Descartes, se desarrolla en Inglaterra el empirismo ${ }^{37}$ que reflejan las aportaciones de F. BACON (1561-1626), T. HobBes (1588-1679), J. LOCKE (1632-1704) y D. Hume (1711-1776). Conforme al empirismo, no tenemos ningún conocimiento más que el de los meros datos que proporcionan los sentidos, poniendo en duda que, partiendo de la experiencia, este tipo de conocimiento pueda leer aquello que de inteligible hay en lo sensible y formar conceptos abstractos, inmateriales y universales.

Por su parte KANT (1724-1804) propone una teoría sobre el conocimiento que, mediando entre el racionalismo y el empirismo, termina por negar la posibilidad de la Metafísica como ciencia especulativa ${ }^{38}$ al no ser sus objetos de conocimiento tradicionales - el alma, el mundo, Dios-posibles contenidos de la experiencia ${ }^{39}$. Rechaza así el carácter científico de los conocimientos que solo alcanzan el nivel de lo verosímil ${ }^{40}$.

\subsection{Del hombre social al individuo egoísta}

Al final de la Edad Media se sustituye la noción teleológica de la naturaleza humana por una concepción de la misma como causa eficiente y con ello se hace imposible comprender al hombre como un ser que naturalmente vive en sociedad. El fin deja de ser una realidad inmanente al hom-

${ }^{36}$ Descartes, R.: Discurso del método. Dióptrica, meteoros y geometría. Prólogo, traducción y notas de Guillermo Quintás Alonso, Alfaguara, Madrid, 1981, pp. 3-55.

${ }^{37}$ Hegel, G. W. F.: Ciencia de la lógica. Traducción de Augusta y Rodolfo Mondolfo, de la edición alemana de 1948. Buenos Aires, Solar-Hachette, 2. ${ }^{\text {a }}$ edición en castellano, 1968, p. 27.

${ }^{38}$ KAnT, I..: Crítica de la razón pura. Prólogo, traducción, notas e índices de Pedro Ribas, Taurus (versión PDF), Madrid. 2005, p. 14.

39 Para Carlos Valverde la posibilidad humana de conocimiento según Kant es más bien pesimista pues niega la posibilidad de conocer las realidades en sí. Estas realidades deben ser pensadas pero no pueden ser conocidas. Conocer sólo se puede conocer el fenómeno a través de la sensibilidad externa o interna. VALVERDE, C.: Antropología filosófica.

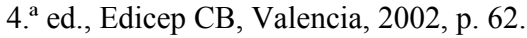

${ }^{40}$ Kant, I..: Crítica de la razón pura. Prólogo, traducción, notas e índices de Pedro Ribas, Taurus (versión PDF), Madrid, 2005, p. 413. 
bre $^{41}$, se elimina la cuestión de la finalidad ${ }^{42}$. En Filosofía Moral se prescinde de la teleología, pieza clave del aristotelismo, y con ello se hace implanteable la pregunta por la vida que es buena para el ser humano o por sus fines ${ }^{43}$.

La influencia de la antropología luterana en filósofos de la época es relevante (Kant, Fitche, Schelling, Hegel, Kierkegaard, Nietzche, Marx, ENGELS... etc.), una antropología pesimista que ve al hombre corrompido por el pecado original, que desprecia la naturaleza y la libertad humanas y que, por influencia del nominalismo, niega valor a todo conocimiento universal. Se critica la Metafísica, se desprecia a la razón y se invita a la introversión y al subjetivismo, acabándose por convertir al hombre en norma absoluta para sí mismo ${ }^{44}$.

La sociedad se entiende desde los individuos que la componen, como un agregado, y con ello los bienes públicos y comunes se descomponen en términos de bienes individuales. La reflexión sobre el hombre se hace materialista, y en este sentido J. BENTHAM (1748-1832) ${ }^{45}$, en la obra exponente de su doctrina utilitarista, señala: «la naturaleza ha situado al género humano bajo el gobierno de dos maestros soberanos, el dolor y el placer» desde los cuales debe determinarse lo que debe y no debe hacerse. A partir de ahí Bentham saca conclusiones que proyectará en el ámbito de la moral, en el político y en el de la legislación. En su Ética ARISTÓTELES también había considerado el placer y el dolor, pero no los adopta como criterio de decisión del hombre que busca la virtud y con ello la felicidad y el bien ${ }^{46}$.

La libertad se interpreta como una «libertad de indiferencia», individualista, consistente en estar libre de obstáculos externos como pueden ser los demás hombres. La simplicidad conceptual de esta idea y su aparente conexión con la vivencia cotidiana de la libertad explican buena parte de su éxito ${ }^{47}$. La pérdida de los fines y del sentido relacional del ser humano, la imposibilidad de conocer el bien objetivo sobre sí mismo y la influencia del subjetivismo, desembocan en lo que ha sido descrito por algunos autores

${ }^{41}$ Spaemann, R.: Lo natural y lo racional: ensayos de antropología. Versión española realizada por Daniel Innerarity y Javier Olmo. Prólogo de Rafael Alvira, Madrid, Rialp, 1989, p. 34.

${ }^{42}$ Espinosa, T. A.: Alasdair MacIntyre: ética contextualizada, Universidad Monteávila, Caracas, 2000, p. 96.

43 Ibidem, p. 115.

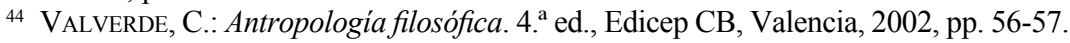

${ }^{45}$ Bentham, J.: An introduction to the principles of morals and legislation, Batoche Books, Kitchener, 2000, p. 14 (Traducción propia).

46 ARISTÓTElEs: Ética nicomaquea, Traducción y notas de Patricio de Azcárate, Buenos Aires, Losada, 2004, p. 55.

${ }^{47}$ Llano, A.: Humanismo cívico, Ariel, Barcelona, 1999, pp. 60 y ss. 
como fragmentación o compartimentación del yo. «La Modernidad desconfía de la discusión racional acerca de los principios, y de las nociones de «vida buena» y por ello trata de abstraerlos, sin pretender alcanzar nociones sustantivas y comprehensivas sobre el bien común» ${ }^{48}$.

\subsection{Del orden al contrato}

El análisis histórico ha situado el origen o embrión del estado moderno hacia el siglo XIII ${ }^{49}$, apuntándose incluso qué alternativas de organización política podían haberse desarrollado desde ese momento en lugar del estadonación ${ }^{50}$. No obstante, es desde el siglo $\mathrm{XVI}^{51}$ cuando esta última opción prevalece sobre el resto, identificándose como notas características del fenómeno la existencia de territorios bien delimitados bajo un mismo control, relativamente centralizados, diferenciados de otras organizaciones, y reforzando su influencia a través de la tendencia a adquirir el monopolio en el uso de la fuerza dentro de su territorio. También se señala al Renacimiento como referencia temporal dónde encontrar indicios de crisis en las sociedades occidentales en su transición desde la Cristiandad medieval al Estado moderno ${ }^{52}$.

Durante los siglos XVI a XVIII una serie de autores permeados de la filosofía y antropología predominantes van aportando los elementos teóricos para una teoría política que cristalizará en el nacimiento del Estado moderno ${ }^{53}$. $\mathrm{T}$. HobBes (1588-1679) elabora su teoría política del contrato ${ }^{54}$ desde la idea de un hombre que no es ni social ni político ${ }^{55}$.

A la fuerza de las ideas se unió la de los acontecimientos. Durante los siglos XVI y XVII Europa se convierte en campo de batalla por intereses religiosos, políticos y territoriales y se crea un clima de desconfianza en las posibilidades del propio hombre de vivir en paz consigo mismo y con los demás hombres.

${ }^{48}$ García de Madariaga, C.: La crítica al concepto liberal de justicia en Alasdair MacIntyre, Tesis doctoral, Universidad Complutense de Madrid, 2004, p. 213.

49 Strayer, J.: On the Medieval Origins of the Modern State, NJ. Princeton University Press, Princeton, 1970, p. 58.

${ }_{50}$ Tilly, C. (ed): The Formation of Nation States in Western Europe, Princeton University Press, Princeton, New Jersey, 1975, p. 23.

${ }_{51}$ Tilly, C. (ed): The Formation of Nation States in Western Europe, Princeton University Press, Princeton, New Jersey, 1975, p. 27.

${ }_{52}$ Rothbard, M. N.: Historia del pensamiento Económico. El pensamiento económico hasta Adam Smith. Vol. I. Unión Editorial, Madrid, 1999, p. 228.

53 Truyol y Serra, A.: Historia de la Filosofía del Derecho y del Estado. 2.Del Renacimiento a Kant, Alianza, Madrid, 12. ${ }^{\text {a }}$ ed., (Revista de Occidente, $1975^{1}$ ), 1995, p. 194.

${ }^{54}$ HobBes, T.: Leviatan o la materia, forma y poder de una república eclesiástica y civil, México, Fondo de cultura económica (primera edición en español), 1940, p. 141.

${ }^{55}$ Ibidem, p. 137. 
Fue en este contexto en el que surge el estado moderno protector ${ }^{56}$, aunque algunos historiadore ${ }^{57}$ señalan que la violencia frente a la que se pide protección al estado, ha sido provocada por los mismos que aspiran a detentar el poder. De hecho, el fenómeno de la guerra y la creación de la maquinaria militar necesaria han sido vinculados con el desarrollo de los sistemas de extracción de recursos de la población y ambos con la creación del estado moderno ${ }^{58}$.

Para algunos autores, el estado concentra y absorbe todo el poder, no solo política sino jurídicamente, arrogándose así el poder de crear el Derecho. Esto puede explicarse en la medida en que el nominalismo, desde el punto de vista político, no fue capaz de proporcionar criterios de ley natural que oponer al Estado, lo que facilitó el creciente absolutismo estatal del Renacimiento ${ }^{59}$. Sin salir del nominalismo, J. BENTHAM ${ }^{60}$, por ejemplo, fundamenta Estado, Moral y Derecho en su utilidad. «Por principio de utilidad se entiende aquel principio conforme al cual se aprueba o desaprueba toda acción... según parezca que aumenta o disminuye la felicidad de aquellos cuyo interés esté afectado...Digo absolutamente cualquier acción, y por tanto no solo

${ }^{56}$ Alvaro D'ORS califica al Estado como organización artificial creada para la resolución de conflictos religiosos y no como desarrollo de la esencial sociabilidad natural del hombre. D'Ors (1999): 147; A. TRUYOL Y SERRA señala que el Estado moderno surge como resultado de un verdadero conflicto entre reyes y príncipes territoriales contra el universalismo imperial y pontificio y contra «el particularismo de los derechos y privilegios feudales, estamentales y corporativos ó municipales». TRUYOL y SERRA, A.: Historia de la Filosofía del Derecho y del Estado. 2.Del Renacimiento a Kant, Alianza, Madrid, 12. ${ }^{\text {a }}$ ed., (Revista de Occidente, $1975^{1}$ ), 1995, p. 115. Para Miguel Ayuso se trata de una entidad artificial fruto del contrato social y dotado de soberanía que se impone como fundamento del orden civil. Vid.: Ayuso, M.: ¿Ocaso o eclispse del Estado? Las transformaciones del derecho público en la era de la globalización, Marcial Pons, Madrid, 2005, pp. 35 y ss; Dalmacio NeGro entiende que el Estado es una forma de orden no natural como el gobierno, sino artificial. Vid.: NEGro PAVÓN, D.: La situación de las sociedades europeas. La desintegración del êthos y el Estado. IIES, Ed. «Francisco de Vitoria» y Unión Editorial, Madrid, 2008, p. 39.

57 Anderson, P.: Lineages of the Absolutist State, London, New Left Books, 1974; Hintze, O.: The Historical Essays of Otto Hintze, Felix Gilbert, Oxford University Press, New York, 1975; TILly, C.: «War Making and State Making as Organized Crime». En Peter Evans, Dietrich Rueschemeyer, and Theda Skocpol (Ed), Bringing the State Back In, Cambridge University Press, Cambridge, 1985, pp. 169-187.

58 Tilly, C. (ed): The Formation of Nation States in Western Europe, Princeton University Press, Princeton, New Jersey, 1975, p. 24.

59 Rothbard, M. N.: Historia del pensamiento Económico. El pensamiento económico hasta Adam Smith. Vol. I. Unión Editorial, Madrid, 1999, p. 103.

${ }^{60}$ Vallet de Goytisolo, J. B.:«El utilitarismo de Bentham y la ciencia de legislar», en García Delgado, José L. ET. ALT. (Coord): Economía española, cultura y sociedad. Homenaje a Juan Velarde Fuertes ofrecido por la Universidad Complutense. Tomo III. Eudema, 1992, pp. 411 y ss. 
cada acción de un individuo sino cada medida de gobierno» ${ }^{61}$. «El fin del gobierno es promover la felicidad de la sociedad, mediante el premio y el castigo...En lo que consista la felicidad, ya lo hemos visto, es en el disfrute de los placeres y en la protección contra el dolor» ${ }^{62}$.

Respecto de la noción de bien común, tan relevante en el periodo anterior desde el punto de vista político y legislativo, cabe resaltar que, no solo existe diferencia entre los contextos conceptuales en los que surgió el término y los que vieron surgir el estado-nación, sino que no existen evidencias empíricas de que la búsqueda del bien común constituya una explicación histórica de su desarrollo ${ }^{63}$.

Desde el punto de vista social se describen distintos fenómenos que afectan a la conciencia colectiva de esa realidad común. Se pasa de un «espacio complejo» con diferentes contextos comunes en los que se solapan áreas de influencia y niveles de autoridad, a un «espacio simple» caracterizado por la dualidad de individuo y estado ${ }^{64}$. También se produce la «ruptura del sistema de vigencias básicas» que configuraba el ethos europeo, el desvanecimiento de «la vieja ética que enseñaba a estar en el mundo» o también la desintegración del sistema de relaciones de confianza consustanciales a ese ethos $^{65}$. Consiste este proceso en confinar a la esfera de lo privado los sistemas de creencias individuales, incluidas las religiosas, manteniendo la esfera pública gobernada únicamente por procesos de racionalización, incluyendo la legislación ${ }^{66}$.

\subsection{De la virtud a la idea, del reparto al poder}

La filosofía jurídica se verá directamente influida por las nuevas filosofías acerca del conocimiento y de la ciencia así como por la antropología y la teoría política que se configuran tras el Renacimiento. Son tres los elementos clave que han contribuido a configurarla: el nominalismo, el racionalismo y el utilitarismo. El efecto de todo ello sobre las nociones de justicia y derecho se hace más evidente conforme se desdibujan conceptos clave que les servían de referencia: finalidad-teleología, proporción, bien común, relación entre las partes y el todo.

${ }^{61}$ Bentham, J.: An introduction to the principles of morals and legislation, Batoche Books, Kitchener, 2000), p. 14 (traducción propia).

${ }_{62}$ Bentham, J.: An introduction to the principles of morals and legislation, Batoche Books, Kitchener, 2000, p. 61 (traducción propia).

${ }^{63}$ Cavanaugh, W. T.: «Killing for the telephone company: Why the nation state is not the keeper of the common good», Modern Theology 20:2 April, 2004, pp. 247 y 250.

${ }^{64}$ Ibidem, p. 251.

${ }^{65}$ Negro Pavón, D.: Lo que Europa debe al Cristianismo, Unión Editorial, Madrid, 2004, pp. 38-39.

${ }_{66}$ ZAMAGNI, S.: «El bien común en la sociedad posmoderna: propuestas para la acción político-económica», Revista Cultura Económica, n. ${ }^{\circ}$ 70, 2007, p. 26. 
Como efecto del nominalismo, al negarse la realidad de los términos abstractos y universales, la filosofía jurídica se aparta de la ciencia clásica aristotélica centrada precisamente en las esencias o cualidades universales. No se admite la realidad de términos jurídicos tan significativos como «justicia», «relación» o «proporción», dejando a la justicia sin su referente externo y objetivo, sin las categorías o esencias (noúmenos) que se manejaban hasta el momento.

En medio de un mundo agobiado por luchas políticas y de religión, fruto en ocasiones de dogmatismos intransigentes, la confianza en la razón humana introdujo un sesgo racionalista en la visión del Derecho natural ${ }^{67}$. El Derecho natural pasa a convertirse en creación de la razón apoyada en sí mis$\mathrm{ma}^{68}$ y como la única manera de fundamentar el Derecho y la Política. Se hace imprescindible que el Derecho sea imperativamente normativizado por una voluntad superior e impuesto de forma coactiva ${ }^{69}$.

Bajo premisas heredadas del nominalismo individualista, del racionalismo voluntarista y del utilitarismo, el Derecho y por tanto la justicia, se convierten en instrumento armonizador de intereses y derechos que se presuponen contradictorios, en «conseguidores» de la máxima utilidad y bienestar para el mayor número, de un orden limitativo y coercitivo que se aleja de la concepción clásica de Derecho como orden de cooperación y colaboración.

Desde el siglo XIV el realismo jurídico clásico va siendo sustituido por el subjetivismo jurídico. Se atribuye a G. DE OCKHAM el desarrollo de la idea de derecho como poder, del derecho que más tarde se llamaría subjetivo ${ }^{70}$. La invención del individuo y de los derechos individuales que tuvo lugar tras la Modernidad implican una privatización del bien y una falsa dicotomía entre persona y sociedad ${ }^{71}$.

67 Truyol y Serra, A.: Historia de la Filosofia del Derecho y del Estado. 2.Del Renacimiento a Kant, Alianza, Madrid, 12. ${ }^{\mathrm{a}}$ ed., (Revista de Occidente, 1975²), 1995, pp. 263 y ss.

${ }_{68}$ Ibidem, pp. 199 y ss.

69 Vallet DE Goytisolo, J.B.: «La Ciencia y el Derecho en la concepción de Inmanuel Kant», Anales de la Real Academia de Ciencias Morales y Politicas, n. ${ }^{\circ} 82,2005$, pp. 112 y ss.

${ }^{70}$ En Filosofía del Derecho buena parte de la doctrina se refiere a este fenómeno. Pueden encontrarse alusiones explícitas al mismo en: TruYol y SERRA, A.: Historia de la Filosofía del Derecho y del Estado.1.De los orígenes a la baja edad media. 14. ${ }^{\mathrm{a}}$ ed., (Revista de Occidente, 1954'), Alianza, Madrid, 2004, p. 417; Hervada XiBerTa, J.: ¿Qué es

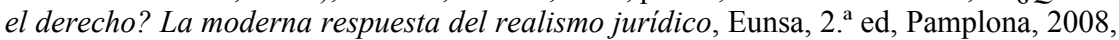
p. 67; VIlley, M.: Filosofía del Derecho. Traducción de Evaristo Palomar Maldonado, Scire Universitaria, Barcelona, 2003, p. 97.

${ }^{71}$ Espinosa, T. A.: Alasdair MacIntyre: ética contextualizada, Universidad Monteávila, Caracas, 2000, p. 172. 


\subsection{El impuesto equitativo}

Coincidiendo parcialmente en el tiempo con lo que hemos denominado cosmovisión moderna, se produce en Europa el nacimiento de la Hacienda Pública primero y su consolidación con la Hacienda clásica después. Se trata este de un periodo de tiempo muy amplio que comienza prácticamente en el siglo XV y que extiende su influencia hasta el siglo XIX.

La Hacienda Pública en su sentido actual y con ello la fiscalidad moderna se puede afirmar que surgen con el nacimiento de los estados nacionales, desarrollándose especialmente en las ciudades-república italianas y en las ciudades libres alemanas del siglo $\mathrm{XV}^{72}$. El fenómeno detonante de este desarrollo se encuentra en las nuevas necesidades de recursos financieros de los príncipes y en la insuficiencia de las fuentes consuetudinarias de ingresos, especialmente impuestos indirectos.

Las aportaciones de la doctrina escolástica se prolongaron hasta el siglo XVII coincidiendo en el tiempo con el nacimiento de la Hacienda Pública, aunque SCHUMPETER ${ }^{73}$ reconoce que la posterior ciencia de la Hacienda nació principalmente de otras raíces. De hecho, en opinión de R. POMINI ${ }^{74}$ esta línea de pensamiento elaborada por hacendistas de formación económica sustituirá a la escolástica al verse esta desplazada por el nominalismo, el racionalismo y el idealismo jurídicos.

La doctrina hacendística reflejó en mayor o menor medida en el campo impositivo las distintas corrientes de pensamiento que sobre el conocimiento, el hombre y la sociedad se iban gestando desde el Renacimiento ${ }^{75}$. En particular, será el individualismo, la idea de sociedad como fruto de un contrato y la creciente contraposición entre las esferas privada y pública algunas de las cuestiones que más incidan en el pensamiento hacendístico. No es casual que haya sido en este marco en el que se haya desarrollado la idea del impuesto como una prima de seguro o como un precio en contraprestación de la seguridad ofrecida por el Estado ${ }^{76}$.

72 Schumpeter, J. A.: Historia del análisis económico. 1. a reimpresión de la edición española de 1994 (edición original de 1954), Ariel, Barcelona, 1995, pp. 242-244.

73 Ibidem, pp. 130 y ss.

${ }^{74}$ PominI, R.: La «causa impositionis». Milán. Giuffré, 1951: Citado por PÉREZ DE Ayala, J. L.: «La imprecisión jurisprudencial sobre la naturaleza jurídica de los principios del artículo 31.1 de la Constitución española. Sus consecuencias», Anales de la Real Academia de Jurisprudencia y Legislación, 2007, n. ${ }^{\text {o } 37, ~ p . ~} 516$.

75 SpIEgel, H.W.: El desarrollo del pensamiento económico. 1. a reimpresión, Omega, Barcelona, 1984, p. 164.

76 PÉrez de Ayala, J. L.: Valoración y significado de las ideas tributarias de Montesquieu, para la dogmática del Derecho Tributario moderno. Discurso leído el día 12 de febrero de 2001 en su recepción pública como académico de número, por el Excmo. Sr. D. José Luis 
Con la transformación de la Hacienda patrimonial en Hacienda monetaria, se irá produciendo la desintegración del vínculo ingreso-gasto, convirtiéndose el impuesto en una prestación abstracta cuya causa descansa directamente en la ley. Este proceso supuso un cambio significativo relacionado con la denominada razón del impuesto y la apariencia unitaria del fenómeno financiero ${ }^{77}$. No obstante, durante el periodo histórico correspondiente al estado constitucional (siglos XVIII y XIX) la conexión entre ingresos y gastos era todavía claramente perceptible en la medida en que la recaudación quedaba objetivamente limitada por lo indispensable para la cobertura de las necesidades públicas ${ }^{78}$.

En el Derecho natural clásico, el bien común como pauta de la justicia general contaba con la utilidad pública como uno de sus elementos. Con la Modernidad se convierte esa parte en un todo y se acusa de imprecisión a la idea de bien común ${ }^{79}$. La contribución impositiva individual es concebida en muchos casos como una contraprestación o pago de los servicios recibidos por el Estado, subrayando de forma expresa el carácter contrapuesto en los intereses de una y de la otra parte. Esta perspectiva se reflejará expresamente en la importancia que se le concede al principio del beneficio o al llamado principio de equivalencia.

Comienza a definirse la actitud del moderno estado resultante del contrato social respecto del ejercicio de la caridad. Se considera que la caridad privada es incierta y con ello se sugiere la necesidad de que el Estado intervenga, todo ello desde la confianza en que su poder es suficiente para acabar con el riesgo y la incertidumbre, con la necesidad humana ${ }^{80}$.

La idea de justicia en el reparto de la carga tributaria se encuentra presente en la doctrina y se identifica, con distintos niveles de concreción, con el principio de proporcionalidad (C. KLOCK, W. PetTy, A. SMith). No obstante, ya se empiezan a reconocer objetivos fiscales (W. PETTY ${ }^{81}$ que pueden

Pérez de Ayala, Conde de Fuensalida y de Cedillo y contestación del Excmo. Sr. D. Juan Vallet de Goytisolo. Real Academia de Jurisprudencia y Legislación, Madrid, 2001, pp. 24 y ss.

77 Rodríguez Bereijo, A. B.: Introducción al estudio del Derecho Financiero: un ensayo sobre los fundamentos teóricos del Derecho Financiero, IEF, Ministerio de Hacienda, 1976, p. 84.

78 Sainz De Bujanda, F. «Estado de Derecho y Hacienda pública», Revista de Administración pública, n. $^{\circ}$ 6, 1951, p. 196.

79 VAllet DE Goytisolo, J. B.: «El utilitarismo de Bentham y la ciencia de legislar», en García Delgado, José L. ET. ALT. (Coord), Economía española, cultura y sociedad. Homenaje a Juan Velarde Fuertes ofrecido por la Universidad Complutense. Tomo III. Eudema, 1992, p. 418.

${ }^{80}$ Gómez de Pedro, M. E.: El Estado del bienestar. Presupuestos éticos y politicos, Tesis doctoral, Barcelona, Universidad de Barcelona, 2000, pp. 192-193.

${ }^{81}$ Hoevel, C.: «The Fiscal and Tributary Philosophy of Antonio Rosmini», Journal of Markets \& Morality, Volume 10, Number 1, 2007, pp. 74-75. 
justificar la posible excepción al mismo. Puede identificarse la idea de justicia como igualdad proporcional (justicia distributiva), aunque el razonamiento para llegar a dicho principio no pone tanto el acento en la existencia de unas cargas comunes como en la relación particular que cada uno establece con el Estado en términos de bienes y servicios (Matteo Palmieri, Carlo A. BorgIA) o en el sacrificio que supone contribuir a su sostenimiento (J. S. MiLL). La capacidad económica continúa siendo el criterio más importante para llevar a la práctica ese tratamiento proporcional (A. SMith, J. S. MiLL, ROSMINI).

El principio del beneficio como forma de realización de la justicia en los tributos entronca de forma particular con la antropología y teoría política de Hobbes $^{82}$. No es extraño encontrar entre los autores de esta época alusión expresa al impuesto como contrapartida por la seguridad y protección que otorga el Estado (C.A. BorgiA, M. PALMIERI) o vinculado a la idea de un contrato.

El principio de progresividad entendido como contribución más que proporcional se encuentra reflejado en la doctrina con distinto grado de aceptación. En todo caso la reflexión sobre el mismo aparece íntimamente ligada a sus posibles efectos económicos.

\section{Cosmovisión cientificista}

Aunque fueron muchas las tendencias de pensamiento que se desarrollaran o surgirán en este periodo, como el idealismo, es destacable la herencia que en el ámbito de las ciencias sociales ha permanecido de una de ellas: el cientificismo o cientifismo ${ }^{83}$.

\subsection{Del racionalismo al método científico}

A modo de síntesis histórica y señalando al mismo tiempo las claves filosóficas más significativas de este periodo, se ha afirmado ${ }^{84}$ que tras la Ilustración y el fracaso de los ideales revolucionarios, el romanticismo generalizó la desconfianza sobre la capacidad del hombre real y comenzó a fraguarse el mito de la regeneración de la humanidad por medio del saber y de la ciencia. También puede observarse cómo el rechazo a la existencia de

82 Álvarez García, S. Y Fernández de Soto Blass, M. . . L.: «Ética y Hacienda Pública: el principio de justicia en la imposición», Crónica Tributaria, n. ${ }^{\circ}$ 111, 2004, p 25.

${ }^{83}$ El cientifismo o cientificismo es una corriente de pensamiento según la cual el único conocimiento riguroso que puede tener el hombre de sí mismo y de cuanto le rodea es el científico (monismo metodológico).

${ }^{84}$ Negro Pavón, D.: El mito del hombre nuevo, Ed. Encuentro, Madrid, 2009. 
un absoluto transcendente va dando paso a la absolutización de otras realidades inmanentes.

El racionalismo kantiano seguido del escepticismo gnoseológico en el que derivaría la búsqueda de certezas del periodo anterior, dio paso a nuevas tendencias entre las que destaca, además del racionalismo idealista de Hegel, el método positivo (A. COMTE, 1798-1857) y lo que se ha denominado cientifismo. El positivismo científico de A. Comte se caracteriza por la intención de aplicar a toda cuestión, moral y social, los métodos científico-experimentales modernos, esto es, atenerse al estudio de los hechos. Este será el estadio final que expresa la Ley de la evolución intelectual de la humanidad ${ }^{85}$, según la cual todas las especulaciones del hombre han pasado primero por el estado teológico (o ficticio), más tarde por el metafísico (o abstracto) y finalmente por el positivo (o real). Las causas finales dejan de interesar a la ciencia por falta de utilidad ${ }^{86}$.

Se produce asimismo una separación radical entre el acto de conocer la realidad y el acto de valorarla, es decir, se trata del rechazo a la posibilidad de extraer del ser criterio normativo alguno. El modo racional de evaluar los hechos o estados de cosas que predomina es por medio del análisis de sus consecuencias, teniendo amplias repercusiones en las ciencias sociales como el Derecho, la Economía o la Política.

\subsection{Del individuo a la sociedad}

La actitud cientificista que se desarrolla especialmente entre los siglos XIX y xx no logra descubrir la singularidad de la vida humana al limitar las vías para acceder a la misma. Las discusiones sobre lo moralmente correcto o incorrecto se dejan al margen por entender que no se trata de un asunto científico sino emocional ${ }^{87}$. Con ello se abandona todavía más la tradición de las virtudes en la consideración de la vida humana en su proyección individual y social. A ello se une la circunstancia de que para muchos de los herederos del liberalismo clásico la economía va a regular no solo las relaciones mercantiles sino las relaciones sociales y políticas.

Desde la Modernidad algunos autores ${ }^{88}$ identifican la paulatina consolidación de una crisis de integración política en las sociedades europeas. Esta crisis se identifica en el decaimiento de la conciencia de pertenecer a unida-

${ }^{85}$ Comte, A.: Discurso sobre el espíritu positivo, Versión y prólogo de Julián Marías, Alianza, Madrid, (Primera edición en Revista de Occidente, 1934), 1980, pp. 17 y ss.

${ }^{86}$ Ibídem, p. 27.

87 ZUBIRI ORIA, I.: «Justicia distributiva: enfoques nuevos a un problema antiguo», Hacienda Pública Española, n. ${ }^{\circ}$ 91, 1984, p. 279.

${ }^{88}$ Llano, A.: Humanismo cívico, Ariel, Barcelona, 1999, p. 5 y ss. 
des sociales que engloben y superen al conjunto de los individuos aislados o en la falta de sentido de pertenencia a grupos. Se busca sin embargo la inserción del individuo en «autonomías libremente elegidas» frente a su vinculación con comunidades tradicionales. Desde otro punto de vista ARENDT ${ }^{89} \mathrm{se}$ refiere a una serie de fenómenos que incrementan la desprotección de un gran número de trabajadores, privándoles de la doble protección que encontraban en la familia y en la propiedad. Así fue cómo la «sociedad» se convirtió en el sujeto del nuevo proceso de la vida, como lo había sido antes la familia. La pertenencia a una clase social remplazó a la protección previamente ofrecida por la familia, y la solidaridad social se convirtió en el muy eficaz sustituto de la anterior y natural solidaridad que regía a la unidad familiar». M. Bu$\mathrm{BER}^{90}$ se refiere también a esta realidad como a la disolución progresiva de las viejas formas organizativas de convivencia humana en las que nacen o ingresan en ella hombres «que no entienden su pertenencia a las mismas como resultado de un acuerdo libre con otros sino como debida al destino o a la tradición vital....la familia, el gremio, la comunidad aldeana, la urbana».

\subsection{Del estado protector al estado benefactor}

El Estado ilustrado da paso al Estado liberal dentro del cual se quiere limitar los poderes y atribuciones como reacción ante el despotismo y el ejercicio abusivo de poder. Bajo la idea de un Estado mínimo, abstencionista, se le pide que intervenga únicamente en la medida en que contribuya a crear las condiciones necesarias para la libre concurrencia, política, económica y social. El Estado se limita así a garantizar la propiedad y los demás derechos innatos del hombre, aquellos de los que disponía en un estadio pre-político o pre-social, en el estado de naturaleza.

Para algunos autores ${ }^{91}$ este proceso introduce la ruptura en el orden jurídico, en la unidad del Derecho, generando, por un lado, un Derecho público o Derecho estatal y, por otro, un Derecho privado en torno a la propiedad o Derecho de la sociedad. El primero de ellos es un ámbito garantizado coactivamente mientras que el segundo constituye una especie de reino de la libertad.

Es en las últimas décadas del siglo XIX donde suele situarse la primera etapa del estado de bienestar, una etapa de experimentación y debate acerca de

89 ARENDT, H.: La condición humana, Traducción de Ramón Gil Novales, Barcelona, Paidós, Reimpresión de la 1. a edición española de 1993 (edición original de 1958), 1996, pp. 277 y ss.

90 Buber, M.: ¿Qué es el hombre?, Fondo de Cultura Económica, México, D.F., 1974, p. 75.

91 Negro Pavón, D.: Lo que Europa debe al Cristianismo, Unión Editorial, Madrid, 2004, pp. 68-69. 
los principios fundamentales, sobre todo del estado. La llegada progresiva de los regímenes parlamentarios permitió la evolución hacia el estado democrático, en el que la soberanía reside en el pueblo y el poder del estado es un poder limitado y delegado. Añade así a sus funciones clásicas (seguridad, defensa, producción legislativa, justicia, moneda...) la de garantizar los derechos civiles y políticos que hacen viable el dinamismo democrático. Los primeros sistemas de previsión social, públicamente instituidos, hacen su aparición.

Tras el desarrollo del fenómeno de los totalitarismos en Europa y como culminación del proceso de limitación del poder estatal desde el principio de legalidad, surge el estado de derecho, que por influencia de las desigualdades socioeconómicas, el movimiento obrero y las ideologías predominantes (socialismo y marxismo), deviene en estado social o de bienestar. La segunda etapa del mismo se ha situado entre los años 20 y los 40 del siglo $\mathrm{XX}$, aunque será en las décadas siguientes en las que se consolide definitivamente. A ello contribuye la puesta en marcha de las políticas keynesianas que convierten al gasto público en pieza clave del crecimiento económico.

Un análisis de los presupuestos teóricos del Estado de bienestar permite relacionar sus fundamentos no solo con la teoría del contrato social sino con otras tendencias y actitudes que acerca del hombre y del conocimiento de la realidad se extienden por Europa durante la Modernidad: el utilitarismo y el consecuencialismo. Ambas tienen su reflejo en las aproximaciones que se hacen al Estado desde la ciencia, como en el caso de la Economía del bienestar ${ }^{22}$, o desde la Teoría de los fallos del mercado y en cómo su razón se vuelve económica y se proyecta en las políticas públicas de asignación, distribución, estabilización y crecimiento. En este contexto, cuestiones clave como la justicia, el bien común, o los principios que aporta la Ética ${ }^{93}$, quedan al margen por no ser susceptibles de tratamiento «científico» o quedar fuera de sus categorías conceptuales.

\subsection{Justicia como derecho positivo}

El positivismo científico aplicado al campo jurídico reduce el Derecho a la exégesis de los textos, renunciando al estudio y consideración de los fines de la actividad judicial ${ }^{94}$. Se extiende la idea, especialmente en el siglo XIX,

${ }^{92}$ Economía del bienestar es una rama de la Economía que aporta los criterios de deseabilidad social de distintos estados de la economía en dónde el protagonismo público ocupa un lugar diferente.

${ }^{93}$ Rosen, Harvey S.: Manual de Hacienda Pública. Ariel Economía, 2. ${ }^{\text {a reimpresión }}$ de la 1. ${ }^{a}$ edición española de 1987. Barcelona, 1994, pp. 79-81.

94 Ihering, Heck, RadBruch, Weber, KELSEN se vinculan con esta corriente ViLley, M.: Filosofia del Derecho. Traducción de Evaristo Palomar Maldonado, Scire Universitaria, Barcelona, 2003, pp. 122-123. 
de que fuera del positivismo como método no puede hacerse «ciencia jurídica»; solo sería «filosofía e ideología del Derecho». «El Derecho natural, más que Derecho sería o Moral o valores relativos, o estructuras lógicas o la naturaleza de las cosas, etc...entendiéndose por Derecho positivo todo derecho cuyo título y cuya medida deben su origen a la voluntad humana manifestada en la ley, la costumbre o el contrato» ${ }^{95}$.

\subsection{Principio de justicia en los tributos}

El principio de justicia en los tributos desarrolla en este periodo buena parte de los elementos más representativos que configurarán a los sistemas fiscales modernos. Se ha señalado que la idea de la relación tributaria como pura relación de poder, de supremacía o subordinación entre el Estado y el ciudadano se consolida con el positivismo liberal durante el siglo XIX. La influencia del positivismo en materia tributaria es clara: «el impuesto en el ordenamiento positivo se basa en principio en consideraciones que no tienen en cuenta si es justo o no atendiendo tanto al elemento objetivo como subjetivo del mismo. Es indiferente al concepto de lo justo, aunque no necesariamente sea contrario a él $»^{96}$. Queda así roto el fundamento meta-jurídico del poder tributario. El tributo, en cuanto que imprescindible para la existencia del Estado, quedaría justificado por la propia existencia del mismo ${ }^{97}$.

En este proceso jugarán un papel esencial los nuevos fines asumidos por el Estado benefactor y las situaciones de necesidad social que históricamente se producen. Como ya se señaló, la relación entre el ingreso impositivo y el gasto público comenzó su desintegración con el desarrollo de la hacienda monetaria.

La idea de fomento y tutela del bien común resulta incómoda dentro del modelo epistemológico positivo, así como la pregunta por los fines del hombre y de la vida en sociedad. Por otro lado, el modelo de hombre individualista que busca sus propios fines y que ve en el otro una limitación para su propio desarrollo, tampoco suscita la formulación de la pregunta por este bien.

La redistribución fue uno de los fines adoptados por los sistemas fiscales cuya influencia resulta clave para entender el sentido y alcance del principio de

${ }^{95}$ Hervada Xiberta, J.: ¿Qué es el derecho? La moderna respuesta del realismo

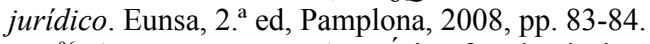

96 Aparicio Pérez, A.: «Ética fiscal y jurisprudencia», en Álvarez García, S. y Herrera Molina, P. (Coords.), Documentos, n. ${ }^{\circ}$ 10/04. IEF, Madrid, 2004, p. 35.

97 Pérez de Ayala, J. L.: Valoración y significado de las ideas tributarias de Montesquieu, para la dogmática del Derecho Tributario moderno. Discurso leído el día 12 de febrero de 2001 en su recepción pública como académico de número, por el Excmo. Sr. D. José Luis Pérez de Ayala, Conde de Fuensalida y de Cedillo y contestación del Excmo. Sr. D. Juan Vallet de Goytisolo. Real Academia de Jurisprudencia y Legislación, Madrid, 2001, pp. 70 y ss. 
justicia en los tributos. Desde el liberalismo clásico y conforme al «principio de utilidad social», se justifica el uso de la fiscalidad como mecanismo redistributivo, en la medida en que este principio debía limitar la búsqueda del interés individual ${ }^{98}$. Ya en el soglo XX, la doctrina tributarista ${ }^{99}$ más relevante en materia de principios impositivos se refiere al cambio producido en las ideas sobre lo que es justo y a la crítica de los resultados distributivos del mecanismo de mercado, justificando la acción equilibradora del Estado mediante medidas coactivas, entre las que se incluyen las fiscales. Se separa así la cuestión de la distribución justa de la carga fiscal de los objetivos de redistribución de renta y riqueza, considerándose ambas relacionadas y compatibles con la idea de justicia en la imposición. El acuerdo que progresivamente se va extendiendo acerca de la función estatal en la distribución de la renta alcanza también a la realización de la caridad ${ }^{100}$. Resultan así relacionados la aparición de los Estados de bienestar con la modificación de las normas de ayuda caritativa o providencial ${ }^{101}$.

La influencia de este proceso en la configuración del principio de justicia y en la forma de interpretarlo fue determinante. La idea de reparto fue dando paso a la de redistribución hasta convertirse en legitimadora del fenómeno tributario $^{102}$. Por otro lado, la presión que ejerció la función redistribuidora sobre el principio de capacidad económica suscitó amplias críticas sobre la idoneidad de este último y desplazó hacia el principio de progresividad la esperanza de solución a las situaciones de necesidad social.

La configuración de los principios tributarios en este periodo recibió muchas influencias desde el ámbito de la Ciencia Económica y en particular desde la doctrina hacendística. Si bien es cierto que es en este periodo cuando empieza a configurarse la dogmática jurídica en torno a los tributos, sus fuentes en materia de principios serán los conceptos y categorías elaborados desde la Hacienda Pública. Se ha afirmado ${ }^{103}$ incluso que por influencia del

98 SAnMartín, José, «El bien común como idea política. John Stuart Mill, los liberales y sus críticos», Foro interno: anuario de teoría política, n. ${ }^{\circ}$ 6, 2006, p. 132.

99 Neumark, F.: Principios de la imposición, Instituto de Estudios Fiscales, Madrid, 2. ${ }^{\text {a }}$ edición (primera edición española de 1973), 1994, p. 44; GERLOFF, W. y NEUMARK, F.: Tratado de finanzas, El Ateneo, Buenos Aires, 1961, p. 399.

${ }^{100}$ Gómez de Pedro, M. E.: El Estado del bienestar. Presupuestos éticos y politicos, Tesis doctoral, Barcelona, Universidad de Barcelona, 2000, p. 205.

101 Ashford, D.: La aparición de los Estados de Bienestar, Traducción de B. Gimeno, Madrid, Ministerio de Trabajo y Seguridad Social, 1989, p. 345.

102 Jouvenel, BeltRAND DE,: La ética de la redistribución, Traducción de Stella Mastrangelo, Katz editores, Madrid,. Conferencias publicadas originalmente por Cambridge University Press en 1950, 2010, p. 103.

${ }^{103}$ PÉRez de Ayala, J. L.: «La imprecisión jurisprudencial sobre la naturaleza jurídica de los principios del artículo 31.1 de la Constitución española. Sus consecuencias», Anales de la Real Academia de Jurisprudencia y Legislación, n. ․ 37, 2007, p. 531. 
nominalismo jurídico se irá atribuyendo a politólogos y economistas, en lugar de a los juristas, la concreción práctica o ejecución política del impuesto justo, todo ello mediante una técnica fiscal que ofrezca soluciones a los problemas prácticos de la imposición más que centrarse en la traslación al Derecho positivo de los axiomas de la tradición escolástica sobre el impuesto justo.

El principio de capacidad económica como pieza clave de la equidad tributaria, aunque definido y fundamentado desde la escolástica y confirmado doctrinalmente por la Hacienda clásica (aunque desde raíces distintas), experimenta no pocas vicisitudes durante este periodo. Por influencia del positivismo jurídico se le negará toda relevancia al entender que no hay más fuente de justicia que la propia ley. Otros autores, que reconocen la necesidad de contar con criterios éticos y de justicia fiscal que estén más allá del Derecho, no reconocen que el principio de capacidad económica sea uno de ellos debido a la imposibilidad filosófica y lógica de demostrar la conexión entre el principio de capacidad económica y la justicia en los tributos ${ }^{104}$.

La interpretación del principio de igualdad en la imposición que se va extendiendo por influencia de la doctrina alemana (LEIBHOLZ), entendido como un mandato de interdicción de la arbitrariedad, admitirá un tratamiento tributario desigual siempre que existan motivos objetivos no arbitrarios ${ }^{105}$ y que lo justifiquen a la luz de la «común conciencia jurídica» ${ }^{106}$. No obstante, la interdicción de la arbitrariedad como contenido de la igualdad tributaria demostrará con el tiempo ser un instrumento insuficiente para controlar la igualdad al ser interpretado de forma reduccionista ${ }^{107}$.

El principio de progresividad no solo adquiere en este periodo el protagonismo que no tenía en la Hacienda Pública clásica, sino que se convierte en elemento esencial de la configuración del principio de justicia en los tributos. $\mathrm{Su}$ legitimidad se fundamenta desde distintas teorías ${ }^{108}$ al tiempo que se le

104 Pérez de Ayala, J. L.: «Las cargas públicas: principios para su distribución», Hacienda Pública Española, n. ${ }^{\circ}$ 59, 1979, pp. 89-90.

105 Palao TABOADA, C.: «Apogeo y crisis del principio de capacidad contributiva», en Estudios jurídicos en homenaje a Federico de Castro, Tecnos, Madrid, 1976, pp. 393 y ss.

${ }^{106}$ Herrera Molina, P. M.: Capacidad económica y sistema fiscal. Análisis del ordenamiento español a la luz del Derecho alemán. Prólogo de K. Tipke, Marcial Pons, Madrid, 1998, pp. 23 y ss.

107 Ibídem, p. 24.

108 Magraner Moreno, F. J.; Martín López, J.: «Impuestos progresivos y justicia fiscal: reflexiones en torno al principio constitucional de progresividad tributaria del artículo 31.1 de la Constitución española», Presente y futuro de la Constitución Española de 1978, Tirant lo Blanch, 2005, pp. 449-464. 
somete a profunda crítica ${ }^{109}$ desde distintos puntos de vista: político, de técnica fiscal, de eficiencia económica o de justicia impositiva. Se apunta incluso que más allá del desincentivo que la redistribución puede provocar en materia de responsabilidad personal, una alta tributación «tiene además la consecuencia indeseable de reducir la esfera de los servicios gratuitos que las personas prestan, en las relaciones de convivencia, sin esperanza de pago, corroyendo con ello la cultura de civilidad que sostiene la civilización liberal» ${ }^{110}$.

\section{Cosmovisión postmoderna}

La cosmovisión postmoderna se ha identificado ${ }^{111}$ con una actitud de desencanto extendida tanto en la sociedad como entre los intelectuales y un rechazo a la posibilidad de alcanzar a priori verdades objetivas. Esta actitud encuentra relacionada con el fracaso histórico de las utopías modernas en su intento de explicar el mundo, el hombre y Dios, desde Descartes hasta MARX.

\subsection{Del positivismo al relativismo}

La consecuencia última del fracaso de los proyectos modernos de transformación social se ha relacionado con la renuncia a buscar fundamentos últimos en los ámbitos del ser y del deber ser. La Postmodernidad, inspirada por los «maestros de la sospecha», MARX, NiETZCHE y FreUd, sostiene la imposibilidad de alcanzar certezas inamovibles, verdades definitivas y para todos, pudiéndose aspirar únicamente a un «pensamiento débil» hecho de verdades provisionales y sospechosas. La defensa de la tolerancia como postulado lleva a la dogmatización del relativismo y lo convierte en cosmovisión predominante $^{112}$.

En distintos ámbitos, científico, filosófico, moral y político, rige el lema del «anarquismo epistemológico», conforme al cuál cualquier pensamiento, cualquier forma de ver la vida, cualquier teoría es válida con tal de que alguien la sostenga.

109 Por todos: Blum, W. J. y Kalven, H.: El impuesto progresivo: un tema dificil. Edición al cuidado de Carlos Fernández de la Torre. Instituto de Estudios Fiscales, 1972, pp. 62 y ss.

110 Jouvenel, Beltrand de,: La ética de la redistribución, Traducción de Stella Mastrangelo, Katz editores, Madrid,. Conferencias publicadas originalmente por Cambridge University Press en 1950, 2010, p. 15.

111 VAlverde, C.: Génesis, estructura y crisis de la modernidad. BAC, Madrid, 1996, pp. 336 y ss.

112 Spaemann, R.: «Europa: comunidad de valores u ordenamiento jurídico», Conferencia pronunciada en la Universidad de Navarra, 2004, p. 7. 


\subsection{Nihilismo y bienestar}

El afán de seguridad del hombre unida a la pérdida de sentido de carácter nihilista, se proyecta en la creciente importancia del tener sobre el ser, constituyéndose el bienestar material en horizonte vital.

Más allá de las cuestiones económicas, una incompleta visión del hombre se apunta ${ }^{113}$ como explicación de la crisis actual de los estados modernos. En el Estado de bienestar domina una visión hedonista del hombre (primero confusión ideológica entre felicidad y placer y después identificación del placer con el bienestar) y con ello una visión parcial del mismo con olvido de otras realidades (espiritual y racional).

El hombre postmoderno experimenta además una grave crisis de identidad, consecuencia en gran medida de la «fragmentación» o «segmentación» en que vive ${ }^{114}$, un conglomerado de papeles sociales, roles personales sin conexión, en los que deja de ser creativo para dejarse llevar por las estructuras con las que interacciona.

\subsection{Estado de bienestar: consolidación y crisis}

Algunos de los reproches que se han formulado respecto a los movimientos de reforma social del siglo Xx y a la disyuntiva entre más igualdad económica o más desigualdad con mayor crecimiento son el haber renunciado a cualquier transformación esencial, la ausencia de ideales que merezcan la pena, la falta de voluntad de cambiar el mundo para mejorarlo ${ }^{115}$, la cortedad de visión, la miopía, temporal y espacial ${ }^{116} \ldots$ etc.

Se ha calificado al Estado de bienestar como la consolidación social y política de un proceso iniciado durante el siglo XVI a través de las teorías de Maquiavelo, Hobbes, Spinoza llegando hasta J. Bentham, S. Mill, J. KeyNES O BEVERIGE ${ }^{117}$. Además del hedonismo que caracteriza la visión antropológica del periodo, será el utilitarismo el que inspire las decisiones políticas y sociales. La sustitución del bien común por el bienestar individual hace

113 Gómez de Pedro, M. E.: El Estado del bienestar. Presupuestos éticos y politicos, Tesis doctoral, Barcelona, Universidad de Barcelona, 2000, pp. 427 y ss.

${ }_{114}$ Macintyre, A.: Tras la virtud. Traducción castellana de Amelia Valcarce, [2001 ${ }^{1}$ ], 4. ${ }^{\mathrm{a}}$ ed., Crítica, Barcelona, 2009, pp. 252 y ss.

115 Jouvenel, Beltrand De, La ética de la redistribución, Traducción de Stella Mastrangelo, Katz editores, Madrid,. Conferencias publicadas originalmente por Cambridge University Press en 1950, 2010, pp. 74-75.

116 Vallet de Goytisolo, J. B.: «El bien común, pauta de la justicia general o social». Revista de estudios políticos, n. ${ }^{\circ} 153-154,1967$, p. 54.

117 Gómez de Pedro, M. E.: El Estado del bienestar. Presupuestos éticos y politicos, Tesis doctoral, Barcelona, Universidad de Barcelona, 2000, pp. 428 y ss. 
imposible introducir una jerarquía en los fines y objetivos buscados por el poder político. Esta situación también tendrá su reflejo en el ámbito impositivo.

A pesar de reconocer los logros indudables del Estado social de bienestar, son repetidas las alusiones doctrinales a los efectos de los programas públicos asistenciales y redistributivos en la destrucción del tejido social y de las redes naturales de solidaridad y cohesión afirmando ${ }^{118}$ incluso del mismo que no teje redes de solidaridad, no arma moralmente a la sociedad. La sociedad moderna excluye la consideración de principios como el de subsidiariedad ${ }^{119}$ porque supone contemplar en el análisis elementos «no verificables científicamente y en consecuencia racionalmente impertinentes $\rangle^{120}$.

\subsection{Formalismo y constructivismo jurídicos}

El positivismo sigue siendo el que modela el quehacer jurídico en los regímenes políticos modernos, contando con la legitimidad que le otorga el sistema ya consolidado de las mayorías parlamentarias. La consolidación del positivismo legalista viene acompañado en esta etapa de una sobreproducción normativa y de un constructivismo jurídico que tratan de regular, ordenar o intervenir, en instancias de la realidad económica, social y cultural que habían permanecido hasta el momento dentro de ámbitos de influencia estrictamente personales o comunitarios. Las categorías del «bien y del mal» ya no forman parte del debate político ${ }^{121}$, sino que de lo que se habla es de «valores».

El contenido y significado del término justicia continúa desviándose de su sentido original conforme va siendo empleado dentro del lenguaje político. Se va cargando de un sentido y de unas connotaciones que remiten más a la satisfacción de las necesidades personales y sociales que al modesto objetivo asignado al término y consistente en dar a cada uno su derecho.

Frente a un cierto resurgimiento del iusnaturalismo durante el siglo xx se reconoce que las nuevas circunstancias socioculturales, tecnológicas, políti-

118 García de Madariaga, C.: La critica al concepto liberal de justicia en Alasdair MacIntyre, Tesis doctoral, Universidad Complutense de Madrid, 2004, p. 89.

119 El término, ya implícito en las aportaciones de ARISTÓTELES (en su Política I, 1, sobre el orden político de la ciudad) y de SANTO TOMÁs (en su Summa contra los Gentiles, III, 71, 4, en relación al respeto del buen gobierno a la naturaleza de las cosas gobernadas) se hace explícito en dos documentos de la Doctrina Social de la Iglesia, en la Rerum Novarum de LEÓN XXIII (n. $\left.{ }^{\circ} 35\right)$, y en la Quadragesimo Anno de Pío XI (n. $\left.{ }^{\circ} 79\right)$.

${ }_{120}$ AyUso, M.: ¿Ocaso o eclispse del Estado? Las transformaciones del derecho público en la era de la globalización, Marcial Pons, Madrid, 2005, p. 31.

121 Spaemann, R.: «Europa: comunidad de valores u ordenamiento jurídico», Conferencia pronunciada en la Universidad de Navarra, 2004. 
cas y económicas imperantes «han favorecido el desinterés por las grandes cuestiones valorativas acerca de la fundamentación del Derecho y de su justicia, incrementando en cambio el interés por sus aspectos meramente formales y preocupándose ante todo por la consecución de un mayor rigor metodológico en lo que se refiere a la creación y aplicación del Derecho positivo, pero infravalorando otros aspectos y convirtiendo la reflexión iusfilosófica en pura lógica jurídica» ${ }^{122}$.

\subsection{Del Estado social al estado fiscal}

Conforme al pensamiento jurídico formalista se considerara que en la norma empieza y acaba el material empírico con el que cuenta el jurista, fenómeno que algunos autores ${ }^{123}$ identifican por ejemplo en el caso español: «En el Derecho español en el impuesto se prescinde en su formulación de la existencia de un elemento de lo justo objetivamente reconocible, apostando por el contrario por una apreciación subjetiva del mismo en el marco de la configuración positivista del sistema». Se señala asimismo la influencia del positivismo en la jurisprudencia de jueces y tribunales afirmando que la misma es deudora de una gnoseología de tipo realista, que vaya más allá de una labor meramente reproductora del Derecho.

La doctrina ${ }^{124}$ recoge también el fenómeno anterior refiriéndose al «Estado fiscal» como la forma que ha adoptado el «Estado social» en nuestra cultura política europea, orientado más hacia la igualdad, hacia la socialización de las necesidades humanas y del modo de satisfacerlas. Esta situación genera crecientes demandas, expectativas, compromisos sociales que se han consolidado para los ciudadanos como derechos adquiridos que presionan, cuando no se imponen, a los poderes públicos.

La multiplicidad de fines que se le han ido atribuyendo a la imposición no ha estado acompañada de una profunda y sistemática reflexión en torno al gasto público como parte de la justicia tributaria. El postulado de que «la justicia de la imposición supone tener en cuenta tanto la cuantía de la renta nacional que va a tomarse para fines colectivos como la forma en que esa cuantía va a distribuirse entre personas diferentes» ${ }^{125}$, no ha sido objeto de

122 Pérez Luño, A. E.: Teoría del Derecho, Tecnos, Madrid, 2004, p. 79.

123 Aparicio PÉrez, A.: «Ética fiscal y jurisprudencia», en Álvarez García, S. y Herrera Molina, P. (Coords.), Documentos, n. ${ }^{\circ}$ 10/04. IEF, Madrid, 2004, pp. 36 y ss.

124 Rodríguez BereiJo, A. B.: Introducción al estudio del Derecho Financiero: un ensayo sobre los fundamentos teóricos del Derecho Financiero. IEF. Ministerio de Hacienda. 1976, pp. 248-249.

125 Buchanan, J. M.: «Los límites éticos a la imposición», Hacienda Pública Española, n. 114 (edición original de 1984), 1990, pp. 231 y ss. 
desarrollo y debate al cuestionarse la existencia de criterios normativos válidos o un concepto de bien común ${ }^{126}$ de referencia.

En materia de principios es destacable un cambio en el paradigma económico vigente que somete a revisión principios tributarios consolidados como el de progresividad por su posible conflicto con el de eficiencia económica. El desarrollo de este principio, al amparo de la Teoría de la imposición óptima y de conceptos como utilidad-coste marginal, preferencias subjetivas, bienestar, incentivos, eficiencia paretiana, etc., herramientas conceptuales aportadas por la Economía, convierte en implanteable una pregunta por lo común que vaya más allá de la mera adición del bienestar o interés material de un colectivo desestructurado. Así, justicia y eficiencia impositivas, dos principios fundamentales del orden social y económico, inspiran reformas fiscales carentes de un modelo de hombre y de sociedad no contradictorios.

La consolidación del Estado de bienestar en el marco antropológico y social ya descrito, le otorga al sistema fiscal un protagonismo evidente que se traduce en sobreproducción normativa y un cierto dirigismo fiscal. Estos fines, en ocasiones opuestos unos a otros, ejercerán una importante presión sobre los principios tributarios, especialmente sobre el de capacidad económica. PÉREZ DE AYALA ${ }^{127}$ por ejemplo, entiende que el elemento de obligatoriedad del concepto actual del tributo está configurado de tal manera que muchos de los presupuestos de gravamen que lo generan no reflejan necesariamente una capacidad económica real, lo que implica algo más que un alejamiento entre el ser y deber ser del tributo. Cuando la ley se aparta del esquema causal en los impuestos (causa eficiente, material, formal, y final), no es que se aleje de su «deber ser» sino que se aparta de la esencia misma del tributo. «Filosóficamente, hemos pasado del realismo al nominalismo. Y, jurídicamente, hemos pasado del ius-naturalismo al positivismo formalista, cuando no al constructivismo jurídico» ${ }^{128}$.

En los ámbitos doctrinal y jurisprudencial esta tendencia se manifiesta en la identificación del principio de igualdad en el ámbito tributario, no tanto con el principio de capacidad económica, sino con el de interdicción de la

126 TIPKE, K.: Moral tributaria del Estado y de los contribuyentes (Besteuerungsmoral und Steuermoral) [2000], Traducción, presentación y notas de Pedro Herrera Molina, Marcial Pons, Madrid, 2002. ${ }^{\text {a }, ~ p . ~} 108$.

127 PÉrez de Ayala, J.L.: «El derecho positivo tributario entre el iusnaturalismo y el constructivismo jurídico. ¿Una antítesis insalvable?», en AA.VV: Responsa Iurisperitorum Digesta, Vol. V, 2003, pp. 219-234.

128 PÉrez de AyAla, J.L.: «El derecho positivo tributario entre el iusnaturalismo y el constructivismo jurídico. ¿Una antítesis insalvable?», en AA.VV: Responsa Iurisperitorum Digesta, Vol. V, 2003,p. 228. 
arbitrariedad $^{129}$. Podría plantearse la pregunta acerca de si la misma ausencia de sentido teleológico en el Estado que puede significar el protagonismo de un principio «de mínimos» como el de interdicción de la arbitrariedad de los poderes públicos, es la que se intuye en este giro interpretativo del principio de igualdad tributaria.

\section{ALGUNAS CONCLUSIONES}

Las concepciones históricamente predominantes sobre el orden político y el protagonismo del Estado en su realización, han inspirado los principios de reforma tributaria en Europa Occidental. Estas concepciones, asentadas sobre modelos antropológicos y sociales limitados, y derivadas de una cambiante actitud epistemólogica ante su esencia y fines, han ido reduciendo el alcance de la pregunta por el sentido de la vida humana en sociedad, el orden político y el papel del sistema tributario respecto de los anteriores.

Los principios impositivos que han protagonizado la evolución de los sistemas fiscales, más allá de su adaptación a situaciones históricas concretas, han reflejado en su contenido e interpretación el devenir del fenómeno jurídico y del concepto de justicia. Estos últimos, influidos desde la Modernidad por corrientes filosóficas recelosas del valor normativo de la realidad, han vaciado al derecho y con ello a los principios tributarios del necesario referente externo de toda realidad de orden, como lo es la realidad social y la jurídica.

Distintas parcelas de la Ciencia económica, apoyadas en referentes antropológicos y marcos conceptuales diversos a los jurídicos, han favorecido la configuración económica de la razón de estado introduciendo entre los principios tributarios fines contradictorios y no confluyentes hacia el bien común.

En el contexto anterior y dentro de la disposición política actual a la reforma de nuestro sistema tributario, se impone un proceso de reflexión y debate sobre la dimensión comunitaria del hombre, el sentido del orden político y fin del sistema tributario respecto de los anteriores. Esa tarea, alentada desde el ámbito político e iluminada desde el doctrinal, debería inspirar la reconsideración de los principios tributarios que precisa toda reforma fiscal.

\section{BIBLIOGRAFÍA}

Álvarez García, S. Y Fernández de Soto Blass, M. a . L.: «Ética y Hacienda Pública: el principio de justicia en la imposición», Crónica Tributaria, n. ${ }^{\circ} 111$, 2004, pp. 19-25.

${ }^{129}$ El profesor TIPKE se plantea si ello no está llevando a desplazar el principio de igualdad y con ello la justicia a un lugar secundario. TIPKE, K.: Moral tributaria del Estado y de los contribuyentes (Besteuerungsmoral und Steuermoral) [2000], Traducción, presentación y notas de Pedro Herrera Molina, Marcial Pons, Madrid, 2002. a , p. 142. 
Anderson, P.: Lineages of the Absolutist State, London, New Left Books, 1974.

Aparicio PÉrez, A.: «Ética fiscal y jurisprudencia», en Álvarez García, S. y Herrera Molina, P. (Coords.), Documentos, n. ${ }^{\circ}$ 10/04. IEF, Madrid, 2004, pp. 25-47.

Aquino, S. T. DE: Suma de Teología II, parte I-II (Prima secundae), BAC, Madrid, 1989.

ARENDT, H.: La condición humana, Traducción de Ramón Gil Novales, Barcelona, Paidós, Reimpresión de la 1. a edición española de 1993 (edición original de 1958), 1996.

ARISTÓTELES: La política, Edición preparada por Carlos García Gual y Aurelio Pérez Jiménez, 2. ${ }^{\text {a }}$ ed., Madrid, Editora Nacional, 1981.

- : Metafísica, Edición trilingüe por Valentín García Yebra, 2. ${ }^{a}$ ed. [1970르, Gredos, Madrid, 1990.

— Ética nicomaquea, Traducción y notas de Patricio de Azcárate, Buenos Aires, Losada, 2004.

AsHForD, D.: La aparición de los Estados de Bienestar, Traducción de B. Gimeno, Madrid, Ministerio de Trabajo y Seguridad Social, 1989.

Ayuso, M.: ¿Ocaso o eclispse del Estado? Las transformaciones del derecho público en la era de la globalización, Marcial Pons, Madrid, 2005.

Bentham, J.: An introduction to the principles of morals and legislation, Batoche Books, Kitchener, 2000.

Blum, W. J. y Kalven, H.: El impuesto progresivo: un tema difícil. Edición al cuidado de Carlos Fernández de la Torre. Instituto de Estudios Fiscales, 1972.

Buber, M.: ¿Qué es el hombre?, Fondo de Cultura Económica, México, D.F., 1974.

Buchanan, J. M.: «Los límites éticos a la imposición», Hacienda Pública Española, n. ${ }^{\circ} 114$ (edición original de 1984), 1990, pp. 231-238.

CAlderon Corredor, Z.: Los principios impositivos de equidad y eficiencia en el sistema fiscal español: una perspectiva antropológica, Tesis doctoral inédita, 2014.

Cavanaugh, W. T.: «Killing for the telephone company: Why the nation state is not the keeper of the common good», Modern Theology 20:2 April, 2004, pp. 243-274.

Comte, A.: Discurso sobre el espíritu positivo, Versión y prólogo de Julián Marías, Alianza, Madrid, (Primera edición en Revista de Occidente, 1934), 1980.

Corts Grau, J.: Historia de la filosofía del derecho, 2. ${ }^{a}$ ed., Editora Nacional, Madrid, 1968.

Descartes, R.: Discurso del método. Dióptrica, meteoros y geometría. Prólogo, traducción y notas de Guillermo Quintás Alonso, Alfaguara, Madrid, 1981.

D’ors, A.: Nueva introducción al estudio del derecho, Cívitas, 1999.

EsPInOSA, T. A.: Alasdair MacIntyre: ética contextualizada, Universidad Monteávila, Caracas, 2000.

García de MADARIAgA, C.: La crítica al concepto liberal de justicia en Alasdair MacIntyre, Tesis doctoral, Universidad Complutense de Madrid, 2004.

Gerloff, W. y Neumark, F.: Tratado de finanzas, El Ateneo, Buenos Aires, 1961.

Gómez CAMACHO, F.: Economía y filosofía moral: la formación del pensamiento económico europeo en la Escolástica española, Síntesis, Madrid. 1998, pp. 293-307. 
Gómez de Pedro, M. E.: El Estado del bienestar. Presupuestos éticos y políticos, Tesis doctoral, Barcelona, Universidad de Barcelona, 2000.

GorosquiETA REYES, J.: «El sistema de ideas tributarias de los teólogos y moralistas principales de la escuela de Salamanca», Hacienda Pública Española, n. ${ }^{\circ} 17$, 1972, pp. 131-150.

Hegel, G. W. F.: Ciencia de la lógica. Traducción de Augusta y Rodolfo Mondolfo, de la edición alemana de 1948. Buenos Aires, Solar-Hachette, 2. ${ }^{a}$ edición en castellano, 1968.

Herrera Molina, P. M.: Capacidad económica y sistema fiscal. Análisis del ordenamiento español a la luz del Derecho alemán. Prólogo de K. Tipke, Marcial Pons, Madrid, 1998.

HeRVADA XIBERTA, J.: ¿Qué es el derecho? La moderna respuesta del realismo jurídico. Eunsa, 2. a ed, Pamplona, 2008.

Hintze, O.: The Historical Essays of Otto Hintze, Felix Gilbert, Oxford University Press, New York, 1975.

HoBBes, T.: Leviatan o la materia, forma y poder de una república eclesiástica y civil, México, Fondo de cultura económica (primera edición en español), 1940.

Hoevel, C.: «The Fiscal and Tributary Philosophy of Antonio Rosmini», Journal of Markets \& Morality, Volume 10, Number 1, pp. 67-84, 2007.

Jouvenel, Beltrand DE,: La ética de la redistribución, Traducción de Stella Mastrangelo, Katz editores, Madrid,. Conferencias publicadas originalmente por Cambridge University Press en 1950, 2010.

Kant, I..: Crítica de la razón pura. Prólogo, traducción, notas e índices de Pedro Ribas, Taurus (versión PDF), Madrid, 2005.

Llano, A.: Humanismo cívico, Ariel, Barcelona, 1999.

Macintyre, A.: Tras la virtud. Traducción castellana de Amelia Valcarce, [2001ㄹ], 4. ${ }^{\mathrm{a}}$ ed., Crítica, Barcelona, 2009.

Magraner Moreno, F. J.: MARTín LóPez, J.: «Impuestos progresivos y justicia fiscal: reflexiones en torno al principio constitucional de progresividad tributaria del artículo 31.1 de la Constitución española», Presente y futuro de la Constitución Española de 1978, Tirant lo Blanch, 2005, pp. 449-464.

Mirrlees, J. ET. Alt.: Diseño de un sistema tributario óptimo. Informe Mirrlees, Introducción y traducción de Julio Viñuela Díaz, Centro de estudios Ramón Areces (1. a edición inglesa de 2011), 2013.

Negro Pavón, D.: Lo que Europa debe al Cristianismo, Unión Editorial, Madrid, 2004.

- : La situación de las sociedades europeas. La desintegración del êthos y el Estado. IIES, Ed. «Francisco de Vitoria» y Unión Editorial, Madrid, 2008.

- : El mito del hombre nuevo. Ed. Encuentro, Madrid, 2009.

Neumark, F.: Principios de la imposición, Instituto de Estudios Fiscales, Madrid, 2. edición (primera edición española de 1973), 1994.

PAlaO TABOADA, C.: «Apogeo y crisis del principio de capacidad contributiva», en Estudios jurídicos en homenaje a Federico de Castro, Tecnos, Madrid, 1976, pp. 377-426.

PÉREZ DE AyAla, J. L.: «Las cargas públicas: principios para su distribución», Hacienda Pública Española, n. ${ }^{\circ}$ 59, 1979, pp. 87-112. 
: Valoración y significado de las ideas tributarias de Montesquieu, para la dogmática del Derecho Tributario moderno. Discurso leído el día 12 de febrero de 2001 en su recepción pública como académico de número, por el Excmo. Sr. D. José Luis Pérez de Ayala, Conde de Fuensalida y de Cedillo y contestación del Excmo. Sr. D. Juan Vallet de Goytisolo. Real Academia de Jurisprudencia y Legislación, Madrid, 2001.

— : «El fundamento deontológico del impuesto, de la Ley fiscal y de la obligación tributaria». En AA. VV. I Jornada Metodológica «Jaime García Añoveros» sobre la metodología académica y la enseñanza del Derecho Financiero y Tributario. Instituto de Estudios Fiscales. Documentos 11/2002, 2002, pp.285-310.

- «La imprecisión jurisprudencial sobre la naturaleza jurídica de los principios del artículo 31.1 de la Constitución española. Sus consecuencias», Anales de la Real Academia de Jurisprudencia y Legislación, n. ${ }^{\text {o } 37, ~ 2007, ~ p p . ~ 513-548 . ~}$

PÉrez Luño, A. E.: Teoría del Derecho, Tecnos, Madrid, 2004.

Petit Sullá, José M. a .: Obras Completas. Tomo II, Vol. II, Tradere, 2011.

PoMINI, R.: La «causa impositionis». Milán. Giuffré, 1951.

Rodríguez Bereijo, A. B.: Introducción al estudio del Derecho Financiero: un ensayo sobre los fundamentos teóricos del Derecho Financiero, IEF, Ministerio de Hacienda, 1976.

- : «Breve reflexión sobre los principios constitucionales de justicia tributaria», Revista jurídica Universidad Autónoma de Madrid, n. ${ }^{\circ}$ 13, 2005, pp. 235-352.

Rosen, Harvey S.: Manual de Hacienda Pública. Ariel Economía, 2. reimpresión de la 1. ${ }^{\text {a }}$ edición española de 1987, Barcelona, 1994.

RothBARD, M. N.: Historia del pensamiento Económico. El pensamiento económico hasta Adam Smith. Vol. I. Unión Editorial, Madrid, 1999.

SAINZ DE BuJANDA, F. «Estado de Derecho y Hacienda pública», Revista de Administración pública, n. ${ }^{\circ} 6,1951$, pp. 193-211.

SANMARTín, José, «El bien común como idea política. John Stuart Mill, los liberales y sus críticos», Foro interno: anuario de teoría política, n. ${ }^{\circ} 6,2006$, pp. 125-153.

SChumpeter, J. A.: Historia del análisis económico. $1 .^{\text {a }}$ reimpresión de la edición española de 1994 (edición original de 1954), Ariel, Barcelona, 1995.

Spaemann, R.: «Sobre la ontología de derechas e izquierdas», Anuario filosófico, n. ${ }^{\circ} 17,1984$, pp. 77-87.

: Lo natural y lo racional: ensayos de antropología. Versión española realizada por Daniel Innerarity y Javier Olmo. Prólogo de Rafael Alvira, Madrid, Rialp, 1989.

- : «Europa: comunidad de valores u ordenamiento jurídico», Conferencia pronunciada en la Universidad de Navarra, 2004.

SPIEGEL, H.W.: El desarrollo del pensamiento económico. 1. ${ }^{\mathrm{a}}$ reimpresión, Omega, Barcelona, 1984.

Strayer, J.: On the Medieval Origins of the Modern State, NJ. Princeton University Press, Princeton, 1970.

Tilly, C. (ed), The Formation of Nation States in Western Europe, Princeton University Press, Princeton, New Jersey, 1975. 
: «Reflections on the History of European State-Making». En TILly, C. (ed), The Formation of Nation States in Western Europe, Princeton, Princeton University Press, New Jersey, 1975, pp. 3-83.

- : "War Making and State Making as Organized Crime». En Peter Evans, Dietrich Rueschemeyer, and Theda Skocpol (Ed), Bringing the State Back In, Cambridge University Press, Cambridge, 1985, pp. 169-187.

TIPKE, K.: Moral tributaria del Estado y de los contribuyentes (Besteuerungsmoral und Steuermoral) [2000], Traducción, presentación y notas de Pedro Herrera Molina, Marcial Pons, Madrid, 2002.

— : «El ordenamiento Jurídico Tributario». En AA. VV. I Jornada Metodológica «Jaime García Añoveros» sobre la metodología académica y la enseñanza del Derecho Financiero y Tributario, Documento n. ${ }^{\circ}$ 11/03, Instituto de Estudios Fiscales, 2002.

Truyol y Serra, A.: Historia de la Filosofia del Derecho y del Estado. 2.Del Renacimiento a Kant, Alianza, Madrid, 12. ${ }^{\text {a }}$ ed., (Revista de Occidente, $1975^{1}$ ), 1995.

- : Historia de la Filosofía del Derecho y del Estado.1.De los orígenes a la baja edad media. 14. ${ }^{\mathrm{a}}$ ed., (Revista de Occidente, 1954ํㅜ), Alianza, Madrid, 2004.

VALLET DE GoYtisolo, J. B.: «El bien común, pauta de la justicia general o social». Revista de estudios políticos, n. $^{\circ} 153-154,1967$, pp. 43-66.

- : «El utilitarismo de Bentham y la ciencia de legislar», en GARCíA DELGADO, JosÉ L. ET. ALT. (Coord), Economía española, cultura y sociedad. Homenaje a Juan Velarde Fuertes ofrecido por la Universidad Complutense. Tomo III. Eudema, 1992, pp. 411-428.

— : ¿Qué es el realismo? Distintas perspectivas con las cuales se enfoca su significado», Anales de la Real Academia de Ciencias Morales y Políticas, n. ${ }^{\circ} 78$, 2001, pp. 583-605.

_- «La Ciencia y el Derecho en la concepción de Inmanuel Kant», Anales de la Real Academia de Ciencias Morales y Políticas, n. ${ }^{\circ}$ 82, 2005, pp. 99-114.

VALVERDE, C.: Génesis, estructura y crisis de la modernidad. BAC, Madrid, 1996.

- Antropología filosófica. 4. ${ }^{\mathrm{a}}$ ed., Edicep CB, Valencia, 2002.

Villey, M.: Filosofía del Derecho. Traducción de Evaristo Palomar Maldonado, Scire Universitaria, Barcelona, 2003.

Vitoria, F. DE: La Justicia. Estudio preliminar y traducción de Luis Fraile Delgado. Madrid. Tecnos, 2001.

ZAMAGNI, S.: «El bien común en la sociedad posmoderna: propuestas para la acción político-económica», Revista Cultura Económica, n. ${ }^{\circ}$ 70, 2007, pp. 23-43.

ZUBIRI ORIA, I.: «Justicia distributiva: enfoques nuevos a un problema antiguo», $\mathrm{Ha}$ cienda Pública Española, n. ${ }^{\circ}$ 91, 1984, pp. 279-301.

TITTLE: Political order and principles of tax reform: an analysis in historical perspective

RESUMEN: Distintos Estados europeos y España en particular, están actualmente inmersos en procesos de reforma fiscal que la crisis económica reciente ha convertido en improrrogable. En ellos sobresalen los esfuerzos 
por hacer compatibles fines tributarios tradicionalmente enfrentados y por asegurar la suficiencia recaudatoria. No obstante, este proceso no se encuentra acompañado del necesario debate politico, doctrinal y social sobre los fundamentos del orden político y sus fines ni del sistema tributario como instrumento al servicio del bien común. En este trabajo se propone un análisis histórico de algunos de los elementos filosóficos, políticos, jurídicos y económicos que más han influido en la configuración de los principios tributarios más importantes, con el objetivo de iluminar el debate público y la acción politica ante posibles reformas fiscales.

PALABRAS CLAVE: orden politico, reforma fiscal, principios tributarios, antropología, bien común

ABSTRACT: Several European States, Spain in particular, are currently engaged in unavoidable tax reforms as a result of the recent economic crisis. In this process, the effort to face traditionally opposite tax principles and to ensure revenue adequacy stands out. However, these efforts are not accompanied by the necessary political, doctrinal and social debate on the foundations of political order, its goals and the tax system as a tool for the common good. This paper aims to provide a historical analysis of some of the philosophical, political, legal and economic key elements that have influenced the setting of the most important tax principles, in order to inspire the public debate and the political actions in future tax reforms.

KEYWORDS: political order, tax reform, tax principles, anthropology, common good

RECIBIDO: 03.11.2015

ACEPTADO: 09.12.2015 